\title{
THIN LAYER DRYING OF ZUCCHINI IN SOLAR DRYER LOCATED IN OSMANIYE REGION
}

\author{
Kamil Neyfel ÇERÇi, Özge SÜFER, Mustafa SÖYLER, Ertaç HÜRDOĞAN, Coşkun ÖZALP
}

\begin{abstract}
In this study, the dehydration behavior of zucchini using solar assisted drying system was examined according to 22 thin layer drying models available in literature The correlation coefficient $\left(R^{2}\right)$, chi-square $\left(X^{2}\right)$ and root mean square error (RMSE) values were calculated to check the suitability of models by non-linear regression analysis. It was found that Cubic and Modified Midilli-1 models were the most suitable equations and their $R^{2}$ values were calculated as 0.99963 . $X^{2}$ and RMSE values of related mathematical expressions were $1.89343 \times 10^{-5}, 1.91692 \times 10^{-5}$ and $0.01685 \times 10^{-3}, 0.01721 \times 10^{-3}$ respectively. In addition, heat transfer, mass transfer and diffusion coefficients, which were important parameters in design of drying systems were also determined as $5.18124 \mathrm{~W} / \mathrm{m}^{2}{ }^{\circ} \mathrm{C}, 1.57129 \times 10^{-7} \mathrm{~m} / \mathrm{s}$ and $2.335718 \times 10^{-9} \mathrm{~m}^{2} / \mathrm{s}$ respectively
\end{abstract}

Keywords: diffusion coefficient; heat and mass transfer coefficient; mathematical modeling

\section{INTRODUCTION}

Drying basically starts with the solution of coupling forces between water and material which will be dried. There is a specific energy requirement and this must be given to material continuously as heating for the evaporation of moisture to the surface and pores of the layer. In this sense, the drying process is the heat and mass transfer processes that take place at the same time $[1,2]$. If product is not dried up sufficiently, it affects the quality of the food negatively due to changes in chemical, biochemical and physical characteristics $[3,4]$.

In this context, scientists have been working on mathematical models and computer simulations to design and develop dryers for efficient dehydration. In order to accurately describe the drying kinetics of food products, mathematical modeling is one of the most appropriate approaches. Factors affecting heat and mass transfer between food product and drying air, deviations in case of equilibrium between product and dry air, the change of physical properties of product, water vapor and air by changing humidity and temperature are considered by using these models [5-10].

In the literature, there are many studies about the determination of heat and mass transfer, mathematical modeling, computer simulations in order to design and develop drying systems for different types of fruit and vegetables [11-16]. Midilli and Kucuk [17] carried out drying experiments for nuts under natural and forced convection in solar assisted drying. The scientists found that the logarithmic model could be the most appropriate model to define thin layer forced solar drying. However, they saw that the two-term model was more appropriate in natural solar drying. Younis et al. [18] carried out experiments for the drying of garlic slices; infrared drying was applied at different air velocities and radiation intensities onto materials. The results indicated that decreasing air velocity and rising radiation intensity caused an increase in drying rate and a decrease in drying time. Bozkır [19] developed a mathematical model in thin film formation of washed apricots. The experiments carried out at different temperatures and velocities. Data from experiments was analyzed by Page's drying equations.

In this work, air solar collector assisted drying system was used for modelling zucchini drying. The zucchini contains mineral elements such as potassium, phosphorus, calcium, magnesium, sodium, iron. There is a great difference in nutritional values between consuming the same amount of fresh zucchini and dried zucchini, but when the benefits are compared, the dried zucchini is almost as useful as the fresh zucchini. Dried zucchini can be used for ready-made sacks, bulgur, rice mixtures, bird and pet food. [20]. To investigate the availability of models, correlation coefficient $\left(R^{2}\right)$, root mean square error (RMSE) and chisquare $\left(\chi^{2}\right)$ values were calculated. In addition, convective mass and heat transfer coefficients were calculated for contributing to the literature in drying design.

Table 1 The devices used for measurements and their specifications

\begin{tabular}{|c|c|c|}
\hline Device & $\begin{array}{c}\text { Measurement } \\
\text { parameters }\end{array}$ & Accuracy \\
\hline Testo 435 air speed probe & Air velocity & $0.1 \mathrm{~m} / \mathrm{s}$ \\
\hline $\begin{array}{c}\text { Ledmer digital } \\
\text { temperature measurement } \\
\text { probe }\end{array}$ & Temperatures & $0.1^{\circ} \mathrm{C}$ \\
\hline $\begin{array}{c}\text { Dikomsan Model } \\
\text { electronic balance }\end{array}$ & Product weight & $0.1 \mathrm{gr}$ \\
\hline $\begin{array}{c}\text { Testo 435 humidity } \\
\text { measuring probe }\end{array}$ & Relative humidity & $2-3 \%$ \\
\hline $\begin{array}{c}\text { Eko model MS-410 type } \\
\text { pyranometer }\end{array}$ & Radiation & - \\
\hline $\begin{array}{c}\text { Laboratory type oven } \\
\text { (JSR, 400, England) }\end{array}$ & $\begin{array}{c}\text { Initial and final moisture } \\
\text { contents of samples }\end{array}$ & - \\
\hline
\end{tabular}

\section{EXPERIMENTAL STUDY}

Schematic illustration and the image of the solar assisted drying system are shown in Fig. 1. The ambient air enters the solar collector (state 1) and leaves the collector (state 2) hotter. Then, hot air is passed to the drying cabinet for drying the products. The drying chamber was designed specifically to distribute hot air uniformly. Finally, the air exits the cabinet with more moisture than when entered the cabinet. More 
detailed information about the system is given in reference [21].

Zucchini samples were procured from Erzin region, Hatay/ Turkey. They were cut into average $47 \mathrm{~mm}$ of diameter and $5 \mathrm{~mm}$ thickness and lined up on the tray.

Tab. 1 shows the devices used for measurements and their specifications.

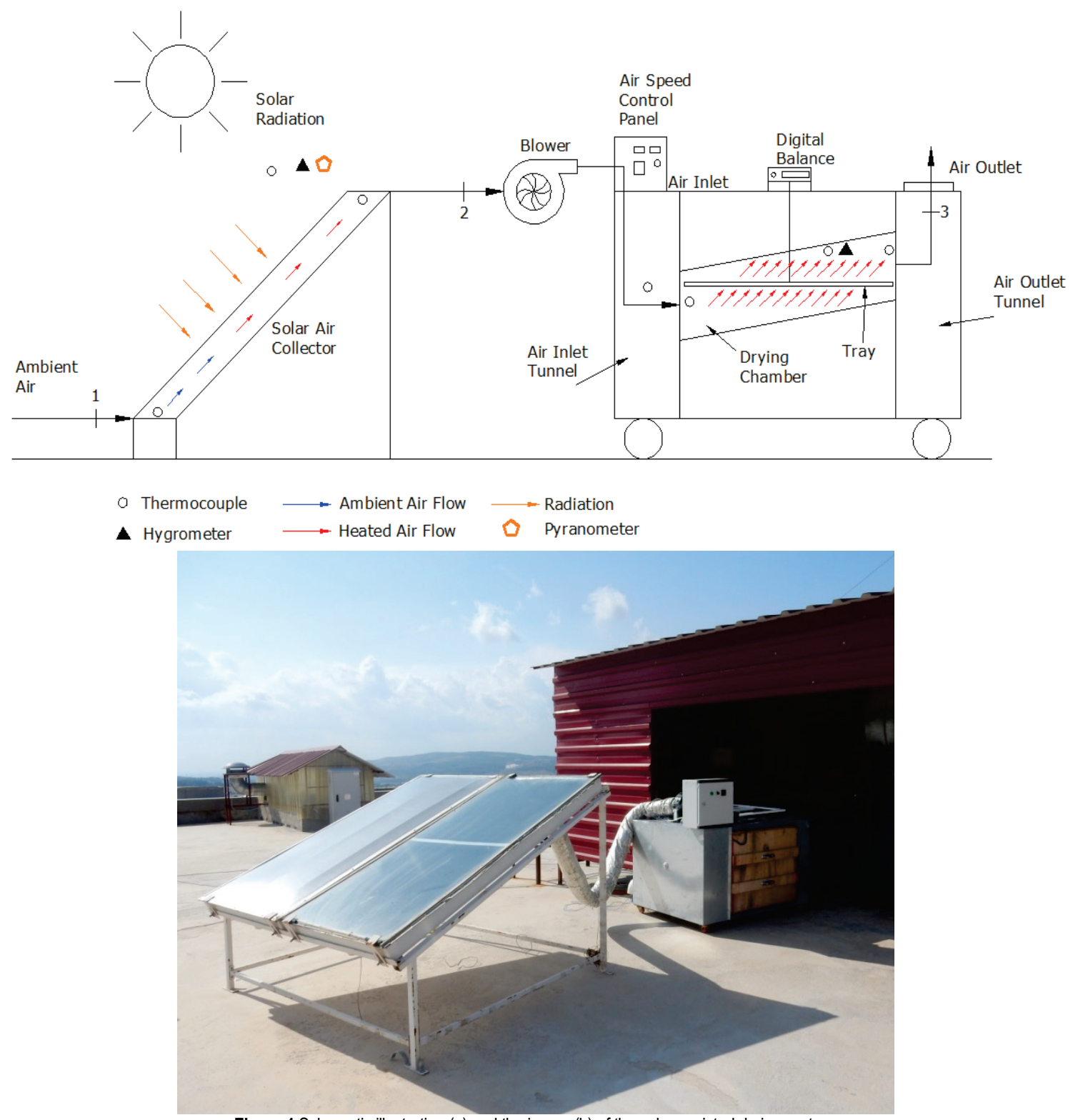

Figure 1 Schematic illustration (a) and the image (b) of the solar-assisted drying system

\subsection{Computation Procedure}

The data obtained from the drying process were fitted to 22 thin layer models given in Tab. 2. $k, k_{0}, k_{1}$ and $n$ denote drying constants and $a, b, c, \mathrm{~d}$ are statistical parameters. (1).

$M R=\frac{M-M_{\mathrm{e}}}{M_{0}-M_{\mathrm{e}}}$

In the related equation, $M$ is the amount of moisture at any time, $M_{\mathrm{e}}$ is the amount of moisture in equilibrium, and $M_{0}$ is initial moisture content. To simplify $M R$, it can be expressed by $M / M_{0}$, because of $M_{\mathrm{e}}$ is lower than $M$ and $M_{0}$ values [42, 43].

Regression analysis was done by using Origin pro program 2016 (Origin Lab, USA).

Correlation coefficients $\left(R^{2}\right)$ were taken as the basic criteria to select the best equation that describes the drying curves of the products [44].

The most suitable model was determined using root mean square error (RMSE) and chi-square $\left(\chi^{2}\right)$ values after $R^{2}$ and calculated as: 


$$
\begin{aligned}
& R M S E=\left[\frac{1}{N} \sum_{i=1}^{N}\left(M R_{\text {exp }, i}-M R_{\text {pre }, i}\right)^{2}\right]^{2} \\
& \chi^{2}=\frac{\sum_{i=1}^{N}\left(M R_{\text {exp }, i}-M R_{\text {pre }, i}\right)^{2}}{N-z}
\end{aligned}
$$

$M R_{\text {exp }, i}$ is an $M R$ value in $i, M R_{\text {pre }, i}$ value is an estimated $M R$ value. $N$ is experiments number, $z$ is constant number. The $M R_{\text {exp }, i}$ is an $M R$ value in $i, M R_{\text {pre }, i}$ value is an estimated $M R$ value. $N$ is experiments number, $z$ is constant number.

Table 2 Different thin layer drying models available in literature

\begin{tabular}{|l|l|c|}
\hline \multicolumn{1}{|c|}{ Model Name } & \multicolumn{1}{c|}{ Equation } & Reference \\
\hline Lewis & $M R=\exp (-k t)$ & {$[22]$} \\
\hline Page & $M R=\exp \left(-k t^{n}\right)$ & {$[23]$} \\
\hline Modified Page & $M R=\exp (-k t)^{n}$ & {$[24]$} \\
\hline $\begin{array}{l}\text { Henderson \& } \\
\text { Pabis }\end{array}$ & $M R=a \exp (-k t)$ & {$[25]$} \\
\hline Logarithmic & $M R=a \exp (-k t)+c$ & {$[26]$} \\
\hline Two-term & $M R=a \exp \left(-k_{0} t\right)+b \exp \left(-k_{1} t\right)$ & {$[27]$} \\
\hline Wang and Singh & $M R=1+a t+b t^{2}$ & {$[28]$} \\
\hline Weibull & $M R=\exp \left(-\left(\frac{t}{b}\right)^{a}\right)$ & {$[29]$} \\
\hline Midilli et al. & $M R=a \exp \left(-k t^{n}\right)+b t$ & {$[30]$} \\
\hline Parabolic & $M R=a+b t+c t^{2}$ & {$[30]$} \\
\hline Cubic & $M R=a+b t+c t^{2}+d t^{3}$ & {$[31]$} \\
\hline Sigmoid & $M R=a+\frac{b}{1+e^{k}(t-c)}$ & {$[32]$} \\
\hline Thompson & $t=a \ln (M R)+b\left[\ln (M R)^{2}\right]$ & {$[33]$} \\
\hline Vega-Lemus & $M R=(a+b t)^{2}$ & {$[34]$} \\
\hline Rational & $M R=\frac{a+b t}{1+c t+d t^{2}}$ & {$[35]$} \\
\hline Vega Galvez-1 & $M R=n+k \sqrt{t}$ & {$[36]$} \\
\hline Vega Galvez-2 & $M R=\exp (n+k t)$ & {$[36]$} \\
\hline Hii et al. & $M R=a \exp \left(-k_{0} t^{n}\right)+b \exp \left(-k_{1} t^{n}\right)$ & {$[37]$} \\
\hline Mod. Midilli-1 & $M R=\exp \left(-k t^{n}\right)+b t$ & {$[38]$} \\
\hline Mod. Midilli-2 & $M R=\exp (-k t)+b t$ & {$[39]$} \\
\hline $\begin{array}{l}\text { Sripinyowanich \& } \\
\text { Noomhorn }\end{array}$ & $M R=\exp \left(-k t^{n}\right)+b t+c$ & {$[40]$} \\
\hline $\begin{array}{l}\text { Noomhorn \& } \\
\text { Verma }\end{array}$ & $M R=a \exp \left(-k_{0} t\right)+b \exp \left(-k_{1} t\right)+c$ & {$[41]$} \\
\hline
\end{tabular}

The effective moisture diffusivity was computed with respect to Fick's second law. Some assumptions can be made within the framework of this law:

a. The humidity distribution is uniform in the cylindrical geometry of the product.

b. Mass transfer is symmetric according to the center of zucchini slice.

c. The surface resistances in mass transfer can be ignored.

d. The diffusion coefficient is assumed to be constant.

The correlation between $M R$ and diffusion coefficient were indicated by Eq. (4):

$M R=\frac{8}{\pi^{2}} \exp \left(-\pi^{2} \frac{D_{e f f}^{t}}{r^{2}}\right)$
$D_{\text {eff }}$ is the diffusion coefficient $\left(\mathrm{m}^{2} / \mathrm{s}\right), r$ is the radius of the samples (m), $t$ is time (s) [45].

Activation energy of zucchini samples was specified using Arrhenius type equations [14]:

$D_{e f f}=D_{0} \exp \left(-\frac{E_{a}}{R T}\right)$

$E_{a}$ is activation energy $(\mathrm{kJ} / \mathrm{mol}), R$ is universal gas constant $(8.3143 \mathrm{~J} / \mathrm{mol} \mathrm{K}), \mathrm{T}$ is ambient temperature $(\mathrm{K})$, and $D_{0}$ is predominant exponential factor $\left(\mathrm{m}^{2} / \mathrm{s}\right)$. The activation energy is formed of the slope of the linearized line of Eq. (5).

Besides, the convective mass transfer coefficient $(\alpha, \mathrm{m} / \mathrm{s})$ was obtained by Eq. (6) [46]:

$\alpha=-\frac{V}{A_{t}} \ln (M R)$

where, $V$ is volume of product $\left(\mathrm{m}^{3}\right), A_{t}$ is product area $\left(\mathrm{m}^{2}\right)$.

The convective heat transfer coefficient $\left(h_{c}, \mathrm{~W} / \mathrm{m}^{2 \circ} \mathrm{C}\right)$ was calculated for forced convection by Eq. (7) [47].

$h_{c}=\frac{N u K_{v}}{x}$ or $h_{c}=\frac{K_{v}}{x} C(\operatorname{Re} \operatorname{Pr})^{n}$

where, $N u$ is Nusselt Number, $K_{v}$ is thermal conductivity $\left(\mathrm{W} / \mathrm{m},{ }^{\circ} \mathrm{C}\right), \operatorname{Re}$ is Reynolds Number, $\operatorname{Pr}$ is Prandtl Number, $C$ and $n$ are constants for calculating heat transfer coefficient value.

The rate of required heat to evaporate moisture $\left(\dot{Q}_{e}\right)$ was computed by Eq. (8) [48].

$\dot{Q}_{e}=0.016 h_{c}\left[P\left(T_{c}\right)-\gamma P\left(T_{e}\right)\right]$

where, $T_{c}$ is product temperature and $T_{e}$ is exit air temperature.

The moisture evaporated was calculated by Eq. (9). Here, Eq. (8) was divided with latent heat of vaporization $(\lambda)$, and multiplied with the area of tray $\left(A_{t}\right)$ and time interval $(t)$.

$\dot{m}_{e v}=\frac{\dot{Q}_{e}}{\lambda} A_{t} t$

where, $Z=0.016 \frac{K_{v}}{x \lambda}\left[P\left(T_{c}\right)-\gamma P\left(T_{e}\right)\right] A_{t} t$

$\frac{\dot{m}_{e v}}{z}=C(\operatorname{Re} \operatorname{Pr})^{n}$

The logarithms of both sides of Eq. (10) are taken,

$\ln \left[\frac{\dot{m}_{e v}}{z}\right]=\ln C+n \ln (\operatorname{RePr})$ 
Eq. (11) similar to an equation of straight line, $Y=b_{1} X+b_{0}$

where, $Y=\ln \left[\frac{\dot{m}_{e v}}{z}\right], b_{1}=n, X=\ln (\operatorname{RePr}), b_{0}=\ln C$

$C$ and $n$ values were determined using linear regression analysis with the obtained experimental data of exit air relative humidity, the product and exit air temperatures and moisture evaporated at the specific time intervals.

The different physical properties of humid air, such as density $\left(\rho_{v}\right)$, thermal conductivity $\left(K_{v}\right)$, specific heat $\left(C_{v}\right)$ and viscosity $\left(\mu_{v}\right)$, were calculated by using $T_{i}$, which is taken as an average of product temperature $\left(T_{c}\right)$ and exit air temperature $\left(T_{e}\right)$ for calculating Reynolds number $(\operatorname{Re})$ and Prandtl number $(P r)$ [49].

$\rho_{v}=\frac{353.44}{\left(T_{i}+273.15\right)}$

$K_{v}=0.0244+0.6773 \times 10^{-4} T_{i}$

$C_{v}=999.2+0.1434 T_{i}+1.101 \times 10^{-4} T_{i}^{2}-6.7581 \times 10^{-8} T_{i}^{3}(14)$

$\mu_{v}=1.718 \times 10^{-5}+4.620 \times 10^{-8} T_{i}$

$P(T)=\exp \left[25.317-\frac{5144}{T_{i}+273.15}\right]$

\section{RESULTS AND DISCUSSION}

In the study, the drying behaviors of the zucchini samples were investigated by using experimental data collected from the solar energy-assisted dryer.

The highest correlation coefficient $\left(R^{2}\right)$ values were found as 0.99963 for Spirinyowanich and Noomhorn, Cubic, Rational, Modified Midilli-1 and Midilli models. The best results of $\chi^{2}$ values were seen in Cubic and Modified Midilli-1 models because of the lowest levels. The values obtained from indicated models were $1.89343 \times 10^{-5}$ and $1.91692 \times 10^{-5}$, respectively. In addition, RMSE values for Cubic and Modified Midilli-1 models were calculated as $0.01685 \times 10^{-3}$ and $0.01721 \times 10^{-3}$ respectively. The values of Spirinyowanich and Noomhorn, Cubic, Rational, Modified Midilli-1 and Midilli models were shown in Table 3 since they have the best correlation coefficient values $\left(R^{2}\right)$.

The variation of the convective mass transfer coefficient $(\mathrm{m} / \mathrm{s})$ and $\ln M R$ values with time were shown in Fig. 2 and 3 respectively.

According to Fig. 2, the convective mass transfer coefficient values varied between $8.65264 \times 10^{-8}$ and $1.97664 \times 10^{-7} \mathrm{~m} / \mathrm{s}$. The average convective mass transfer coefficient was calculated as $1.57129 \times 10^{-7} \mathrm{~m} / \mathrm{s}$. The average diffusion coefficient of zucchini samples was obtained as $2.33572 \times 10^{-9} \mathrm{~m}^{2} / \mathrm{s}$. It is seen that the diffusion coefficient values calculated in this study are in accordance with the literature $[50,51,52,53]$.

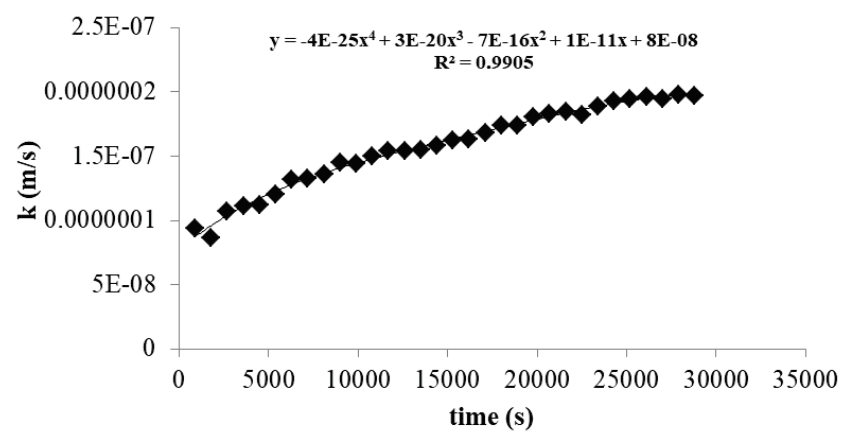

Figure 2 Variation of mass transfer coefficient with drying time

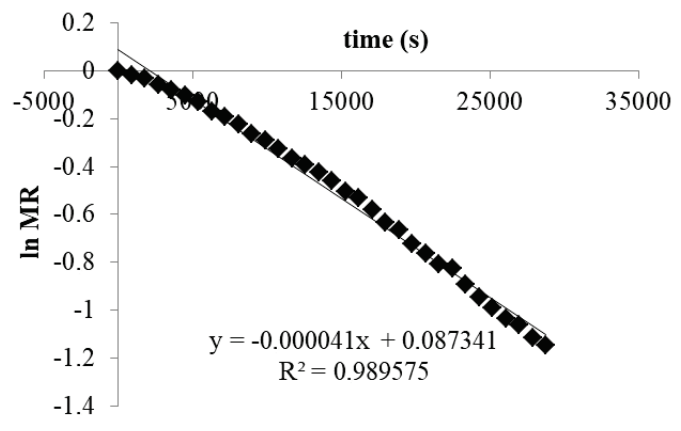

Figure $3 \ln M R$ with drying time

The variations in convective heat transfer coefficient with time are presented in Fig. 4.

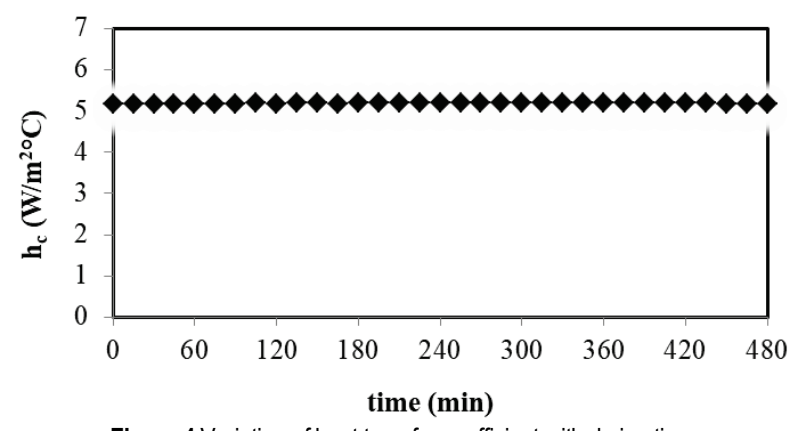

Figure 4 Variation of heat transfer coefficient with drying time

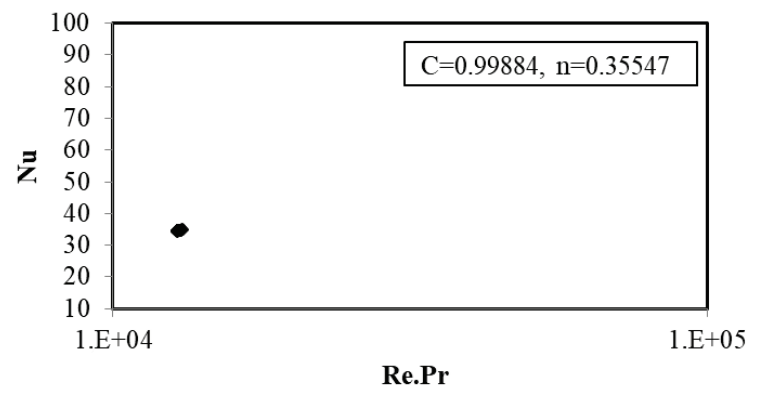

Figure 5 The relation between $\mathrm{Nu}-\mathrm{Re} \cdot \operatorname{Pr}$ for zucchini samples drying at forced convection

The convective heat transfer coefficient values varied between $5.16841-5.18672 \mathrm{~W} / \mathrm{m}^{2 \circ} \mathrm{C}$ during drying process. The variation remained almost constant during drying. The air 
velocity, which is an important parameter in forced convection is kept constant during the experiment. Akpinar [50, 54], evaluated convective heat transfer coefficient values for different food products for forced convection in literature. The convective heat transfer coefficient values varied at between 0.644 and $10.94 \mathrm{~W} / \mathrm{m}^{2 \circ} \mathrm{C}$. It was seen that these values are in accordance with the literature $[50,54]$.

The relation between Nusselt and Reynolds-Prandtl numbers were given in the following graph (Fig. 5).
It could be seen from the figure that the heat transfer carried out under the laminar regime because of $\operatorname{Re} \cdot \operatorname{Pr} \leq 10^{5}$ [55]. The Nusselt number values of the zucchini samples were found between 34.29895-34.76936. Also, C and n constants were found 0.99884 and 0.35547 respectively. Similar results were found by Jain and Tiwari [56]. They indicated laminar regime on drying of peas in greenhouse dryer for forced convection.

Table 3 The statistical parameters of Spirinyowanich and Noomhorn, Cubic, Rational, Modified Midilli-1 and Midilli models

\begin{tabular}{|l|c|c|c|c|c|c|c|c|c|c|}
\hline \multicolumn{1}{|c|}{ Model name } & $R^{2}$ & $\chi^{2}$ & $S S E$ & $R M S E$ & $k$ & $n$ & $a$ & $b$ & $c$ & $d$ \\
\hline Midilli et al. & 0.99963 & $0.00193 \times 10^{-2}$ & 0.00056 & $0.01698 \times 10^{-3}$ & 0.00038 & 1.29122 & 0.99809 & - & - & - \\
\hline Mod. Midilli-1 & 0.99963 & $0.00189 \times 10^{-2}$ & 0.00057 & $0.01721 \times 10^{-3}$ & 0.00041 & 1.27906 & - & -0.00005 & - \\
\hline $\begin{array}{l}\text { Spirinyowanich } \\
\text { \& Noomhorn }\end{array}$ & 0.99963 & $0.00193 \times 10^{-2}$ & 0.00056 & $0.01698 \times 10^{-3}$ & 0.00038 & 1.29093 & - & -0.00004 & -0.00192 & - \\
\hline Cubic & 0.99963 & $0.00191 \times 10^{-2}$ & 0.00056 & $0.01685 \times 10^{-3}$ & - & - & 1.00634 & -0.00137 & $0.00001 \times 10^{-1}$ & 0 \\
\hline Rational & 0.99963 & $0.00196 \times 10^{-2}$ & 0.00057 & $0.01729 \times 10^{-3}$ & - & - & 1.00347 & -0.00081 & 0.00042 & 0 \\
\hline
\end{tabular}

\section{CONCLUSIONS}

In this work, air solar collector assisted drying system was used to investigate the availability of the models for zucchini drying. The correlation coefficient $\left(R^{2}\right)$, root mean square error (RMSE) and chi-square $\left(\chi^{2}\right)$ were calculated. It was seen that the highest values for the correlation coefficient were found as 0.99963 in Spirinyowanich and Noomhorn, Cubic, Rational, Modified midilli-1 and Midilli models. Besides, the lowest values of the chi-square were obtained in Cubic and Modifid Midilli-1 models. Also, RMSE values of those models were computed as $0.01685 \times 10^{-3}$ and $0.01721 \times 10^{-3}$ respectively. Finally, the convective mass and heat transfer coefficients and diffusion coefficient, which are important parameters in determining the drying performance, have been calculated. The average convective mass transfer coefficient and diffusion coefficient were calculated as $1.57129 \times 10^{-7} \mathrm{~m} / \mathrm{s}$ and $2.33572 \times 10^{-9} \mathrm{~m}^{2} / \mathrm{s}$ respectively. The average convective heat transfer coefficient for forced convection was calculated as $5.18124 \mathrm{~W} / \mathrm{m}^{2 \circ} \mathrm{C}$. Also, $\mathrm{C}$ and $\mathrm{n}$ values, which are used for calculating convective heat transfer coefficient, were found as 0.99884 and 0.35547 respectively.

\section{Acknowledgment}

This work was supported by the Department of Energy Systems Engineering under OKÜ scientific research project unit (project no: OKÜBAP-2014-PT3-032), Turkey.

Note: This research was presented at the International Advanced Researches and Engineering Congress, IAREC 2017 (16-18 November 2017, Osmaniye, Türkiye).

\section{REFERENCES}

[1] Yaşartekin, Y. (1991). Kabinet tipi güneş enerjili kurutucunun tasarımı ve tarımsal ürünlerin kurutulmasında denenmesi, MSc Thesis, Ege University, İzmir.

[2] Çınar, H. (2009). Muğla iklim koşullarında havalı güneş toplaçlı 1S1 pompalı kereste kurutma tesisinde kurutma ekonomisinin araştırılması. MSc Thesis, Muğla University, Muğla.
[3] Fellows, P. (2000). Food processing technology principles and practice, $2^{\text {nd }}$ Edition, Boca Raton and Cambrige, CRC Press.

[4] Yemmireddy, V. K., Chinnan, M. S., Kerr, W. L., \& Hung, Y. C. (2006). Effect of drying method on drying time and physico-chemical properties of dired rabbiteye blueberries. LWT-Food Science and Technology, 50(2), 739-745. https://doi.org/10.1016/j.lwt.2012.07.011

[5] Brooker, D. B., Bakker-Arkema, F. W., \& Hall, C. W. (1982). Drying cereal grains, Westport, CT: AVI Publishing Co.

[6] Courtois, F., Lebert, A., Lasseran, J. C., \& Bimbenet, J. J. (1991). Simulation of industrial dryers: solving numerical and computer problems. Drying Technology, 9(4), 927-945. https://doi.org/10.1080/07373939108916728

[7] Khatchatourian, O. A., Borges, P. A. P., \& Vielmo, H. A. (2003). Simulation of soy grains drying Dynamics in camera of fixed bed. Proceeding of the $17^{\text {th }}$ International Congress of Mechanical Engineering / Sao Paulo, Brazil.

[8] Khatchatourian, O. A. \& Olieira, F. A. (2006). Mathematical modelling of airflow and thermal state in large aerated grain storage. Biosystems Engineering, 95(2), 159-169.ž https://doi.org/10.1016/j.biosystemseng.2006.05.009

[9] Parry, J. L. (1985). Mathematical modelling and computer simulation of heat and mass transfer in agricultural grain drying: a review. Journal of Agricultural Engineering Research, 32(1), 1-29. https://doi.org/10.1016/0021-8634(85)90116-7

[10] Celma, A. R., Rojas, S., \& Lopez-Rodriguez, F. (2008). Mathematical modelling of thin-layer infrared drying of wet olive husk. Chemical Engineering and Processing, 47, 18101818. https://doi.org/10.1016/j.cep.2007.10.003

[11] Khatchatourian, O. A. (2012). Experimental study and mathematical model for soya bean drying in thin layer. Biosystems engineering, 113, 54-64. https://doi.org/10.1016/j.biosystemseng.2012.06.006

[12] White, G. M., Bridges, T. C., Loewer, O. J., \& Ross, I. J. (1981). Thin-layer drying model for soybeans. Transaction of ASAE, 6, 1643-1646. https://doi.org/10.13031/2013.34506

[13] Wang, C. Y. \& Singh, R. P. (1978). A single layer drying equation for rough rice, ASAE, 78-3001.

[14] Akpinar, E., Midilli, A., \& Bicer, Y. (2003). Single layer drying behavior of potato slices in a convective cyclone dryer and mathematical modelling. Energy Conversion and Management, 44, 1689-1705. https://doi.org/10.1016/S0196-8904(02)00171-1 
[15] Akpinar, E. K., Bicer, Y., \& Yildiz, C. (2003). Thin layer drying of red pepper. Journal of Food Engineering, 59, 99104. https://doi.org/10.1016/S0260-8774(02)00425-9

[16] Ross, I. J. \& White, G. M. (1972). Thin-layer drying characteristics of white corn. Transaction of ASAE, 15, 175179. https://doi.org/10.13031/2013.37859

[17] Midilli, A. \& Küçük, H. (2003). Mathematical modeling of thin layer drying of pistachio by using solar energy. Energy Conversion and Management, 44(7), 1111-1122. https://doi.org/10.1016/S0196-8904(02)00099-7

[18] Younis, M., Abdelkarim, D., \& El-Abdein, A. Z. (2017). Kinetics and mathematical modeling of infrared thin-layer drying of garlic slices. Saudi Journal of Biological Sciences.

[19] Bozkir, O. (2006). Thin-layer drying and mathematical modelling for washed dry apricots. Journal of Food Engineering, 77, 146-151. https://doi.org/10.1016/j.jfoodeng.2005.06.057

[20] http://www.kurucum.com/kabak-kurusu.html (Accessed: 05.09.2017)

[21] Akman, H. (2017). Güneş Enerjisi Destekli Bir Kurutma Sisteminin Termodinamik Analizi, MSc Thesis, Osmaniye Korkut Ata University, Osmaniye.

[22] Bruce, D. M. (1985). Exposed layer barley drying, three models fitted to new data up to $150{ }^{\circ} \mathrm{C}$. Journal of Agricultural Engineering Research, 32, 337-47. https://doi.org/10.1016/0021-8634(85)90098-8

[23] Page, G. E. (1949). Factors influencing the maximum rates of air drying shelled corn in thin layers (M.S. thesis), Purdue, USA: Department of Mechanical Engineering, Purdue University.

[24] White, G. M., Ross, I. J., \& Ponelert, R. (1981). Fullyexposed drying of popcorn. Transactions of the ASAE, 24, 466-468. https://doi.org/10.13031/2013.34276

[25] Henderson, S. M. \& Pabis, S. (1961). Grain drying theory I: temperature effect on drying coefficient. Journal of Agricultural Engineering Research, 6, 169-74.

[26] Toğrul, I. T. \& Pehlivan, D. (2002). Mathematical modelling of solar drying of apricots in thin layers. Journal of Food Engineering, 55, 209-216. https://doi.org/10.1016/S0260-8774(02)00065-1

[27] Henderson, S. M. (1974). Progress in developing the thin layer drying equation. Transactions of the ASAE, 17, 11671172. https://doi.org/10.13031/2013.37052

[28] Wang, C. Y. \& Singh, R. P. (1978). Use of variable equilibrium moisture content in modelling rice drying. Transactions of the ASAE, 11, 668-672.

[29] Corzo, O., Bracho, N., Pereira, A., \& Vasquez, A. (2008). Weibull distribution for modelling air drying of coroba slices. LWT-Food Science and Technology, 41, 2023-2028. https://doi.org/10.1016/j.lwt.2008.01.002

[30] Sharma, G. P. \& Prasad, S. (2004). Effective moisture diffusivity of garlic cloves undergoing microwave-convective drying. Journal of Food Engineering, 65, 609-617. https://doi.org/10.1016/j.jfoodeng.2004.02.027

[31] Dalvand, M. J., Mohtasebi, S. S., \& Rafiee, S. (2012). Determining the influence of drying conditions on EHD drying process. Journal of Agricultural and Biological Science, 7, 396-401.

[32] Figiel, A. (2009). Drying kinetics and quality of vacuummicrowave dehydrated garlic cloves and slices. Journal of Food Engineering, 94, 98-104. https://doi.org/10.1016/j.jfoodeng.2009.03.007

[33] Thompson, T. L., Peart, R. M., Foster, \& G. H. (1968). Mathematical simulation of corn drying - a new model. Transactions of ASAE, 11, 582-586. https://doi.org/10.13031/2013.39473

[34] Vega-Galvez, A., Di Scala, K., \& Rodriguez, K. (2009). Effect of air- drying temperature on physico-chemical properties, antioxidant capacity, colour and total phenolic content of red pepper (Capsicum annum, L. var. Hungarian). Food Chemistry, 117, 647-653. https://doi.org/10.1016/j.foodchem.2009.04.066

[35] Haghi, A. K. \& Angiz, F. Z. (2007). Heat and mass transfer in thermal drying of wool: A theoretical approach. Proceedings of the $5^{\text {th }}$ Asia-Pasific Drying Conference / Hong Kong, 443448. https://doi.org/10.1142/9789812771957_0065

[36] Lemus-Mondaca, R., Miranda, M., Grau, A. A., Briones, V., Villalobos, R., \& Vega-Gálvez, A. (2009). Effect of osmotic pretreatment on hot air drying kinetics and quality of Chilean papaya (Carica pubescens). Drying Technology, 27(10), 1105-1115. https://doi.org/10.1080/07373930903221291

[37] Hii, C. L., Law, C. L., \& Cloke, W. (2009). Modeling using a new thin layer drying model and product quality of cocoa. Journal of Food Engineering, 90, 191-198. https://doi.org/10.1016/j.jfoodeng.2008.06.022

[38] Ghazanfari, A., Emami, S., Tabil, L. G., Panigrahi, S. (2006). Thin-layer drying of flax fiber: II. Modeling drying process using semi-theoretical and empirical models. Drying Technology, 24, 1637-1642. https://doi.org/10.1080/07373930601031463

[39] Erbay, Z. \& Icier, F. (2010). A review of thin-layer drying of foods: theory, modeling, and experimental results. Critical Reviews in Food Science and Nutrition, 50(5), 441-464. https://doi.org/10.1080/10408390802437063

[40] Sripinyowanich, J. \& Noomhorm, A. (2011). A new model and quality of unfrozen and frozen cooked rice dried in a microwave vibro-fluidized bed dryer. Drying Technology, 29, 735-748. https://doi.org/10.1080/07373937.2010.535399

[41] Noomhorn, A. \& Verma, L. R. (1986)Generalized singlelayer rice drying models. Transactions of the ASAE, 29(2), 587-591. https://doi.org/10.13031/2013.30194

[42] Doymaz, I. (2004). Effect of pre-treatments using potassium metabisulphite and alkaline ethyl oleate on the drying kinetics of apricots. Biosystems Engineering, 89, 281-287. https://doi.org/10.1016/j.biosystemseng.2004.07.009

[43] Kingsly, R. P. \& Singh, D. B. (2007). Drying kinetics of pomegranate arils. Journal of Food Engineering, 79, 741-744. https://doi.org/10.1016/j.jfoodeng.2006.02.033

[44] Doymaz, I. (2004). Effect of dipping treatment on air drying of plums. Journal of Food Engineering, 64, 465-470. https://doi.org/10.1016/j.jfoodeng.2003.11.013

[45] Mota, C. L., Luciano, C., Dias, A., Barroca, M. J., \& Guine, R. P. F. (2010). Convective drying of onion: Kinetics and nutritional evaluation. Food and Bioproducts Processing, 88, 115-123. https://doi.org/10.1016/j.fbp.2009.09.004

[46] Kaya, A., Aydin, O., \& Demirtas, C. (2007). Concentration boundary conditions in the theoretical analysis of convective drying process. Journal of Food Process Engineering, 30(5), 546-577. https://doi.org/10.1111/j.1745-4530.2007.00131.x

[47] Pitts, D. R. \& Sissom, L. E. (1977). Theory and problems of heat transfer. McGraw-Hill Book Company.

[48] Malik, M. A. S., Tiwari, G. N., Kumar, A., \& Sodha, M. S. (1982). Solar distillation. Pergamon Press, Oxford.

[49] Tiwari, G. N. \& Suneja, S. (1997). Solar thermal engineering systems. Narosa Publishing House, New Delhi.

[50] Akpinar, E. \& Toraman, S. (2016). Determination of drying kinetics and convective heat transfer coefficients of ginger slices. Heat Mass Transfer, 52, 2271-2281. https://doi.org/10.1007/s00231-015-1729-6

[51] Thorat, I. D., Mohapatra, D., Sutar, R. F., Kapdi S. S., \& 
Jagtap D. D. (2010). Mathematical modeling and experimental study on thin-layer vacuum drying of ginger (Zingiber officinale R.) slices. Food Bioprocess Technol. https://doi.org/10.1007/s11947-010-0429-y

[52] Jayashree, E. \& Visvanthan, R. (2013). Studies on thin layer drying characteristics of ginger (Zingiber officinale) in a mechanical tray drier journal of plantation crops. J Spices Aromat Crops, 41(1), 86-90.

[53] Afolabi, J. T., Tunde-Akintunde, T. Y., \& Oyelade, O. J. (2014). Influence of drying conditions on the effective moisture diffusivity and energy requirements of ginger slices. J Food Res, 3(5), 103-112. https://doi.org/10.5539/jr.v3n5p103

[54] Akpinar, E. K. (2004). Experimental determination of convective heat transfer coefficient of some agricultural product in forced convection drying. Int Commun Heat Mass Transfer, 31(4), 585-595. https://doi.org/10.1016/S0735-1933(04)00038-7

[55] Holman, J. P. (1992). Heat transfer, $7^{\text {th }}$ ed., SI Unit, McGrawHill Book Company, Berlin.

[56] Jain, D. \& Tiwari, G. N. (2004). Effect of greenhouse on crop drying under natural and forced convection I: Evaluation of convective mass transfer coefficient. Energy Conversion and Management, 45, 765-783.

https://doi.org/10.1016/S0196-8904(03)00178-X

\section{Authors' contacts:}

Kamil Neyfel ÇERÇi, Res. Assist.

Mustafa SÖYLER, Res. Assist.

Ertaç HÜRDOĞAN, Assoc. Prof. Dr., Corresponding author

Coşkun ÖZALP, Assoc. Prof. Dr.

Department of Energy Systems Engineering,

Osmaniye Korkut Ata University,

Osmaniye, 151-742, Turkey,

+90328 8251818-3503/+90328 8250097 ,

ehurdogan@osmaniye.edu.tr

Özge SUFER, Res. Assist.

Department of Food Engineering,

Osmaniye Korkut Ata University,

Osmaniye, 151-742, Turkey, 